\title{
Some Pharmaceutical Recipes for the Treatment of the Bubonic Pest Contained into the Kitab Al-Tahsil of Ibn Khatima (D.1369)
}

\author{
Luisa Maria Arvide Cambra \\ Department of Philology. University of Almeria. Spain \\ *Corresponding Author: 1marvide@ual.es
}

Copyright (C) 2013 Horizon Research Publishing All rights reserved.

\begin{abstract}
This paper is a study of fragments of the work entitled in Arabic Tahsil gharad al-qasid fi-tafsil al-marad al-wafid, which was written in the $14^{\text {th }}$ century by the well known Spanish physician Ibn Khatima and which refers to the epidemics of the pest, the terrible pandemic that struck humanity in the $14^{\text {th }}$ century and devastated Asia, Africa and Europe at that time. The article includes an Introduction about the author and the medical and pharmaceutical significance of the work, as well as a section containing the English translation of a few pages of Part VI, according to the Arabic manuscript 1785 from the Library of El Escorial, relating to the treatment of disease, that contain interesting remedies and recipes from the pharmaceutical and the medical points of view.
\end{abstract}

Keywords Ibn Khatima, Bubonic Pest, Arabic Medieval Pharmacology, Arabic Medieval Medicine, Epidemics.

\section{Introduction}

Abu Dja'far Ahmad ibn 'Ali ibn Muhammad ibn Khatima Al-Ansari, known as Ibn Khatima, is one of the most important intellectuals of the Medieval Moorish Spain (1). He wrote works in different fields, such as literature (poetry), history and medicine (2), and his major work in the sphere of medicine is entitled Tahsil gharad al-qasid fi-tafsil al-marad al-wafid (Achieving the goal of clarifying the disease of the pest) (3), which is collected in three Arabic manuscripts: a) no.1785 from the Library of El Escorial in Spain, the most complete of them; b) no.6369 from Deutsche Staatsbibliothek zu Berlin, in Germany, very close to the manuscript of the Escorial but more fragmented than it; and c) no.CCLXVIII from National Library of Madrid, in Spain, which is a literal copy of the manuscript of El Escorial (4).

The work is divided into ten questions or parts. The six first refer to medical topics: causes, symptoms and treatment to combat the plague; and the four remaining are of religious nature and deal about what Islam says about the epidemics and the plagues (5).

The pandemic of the $14^{\text {th }}$ century that according to Ibn Khatima originated in China soon spread throughout the world and caused millions of dead.

The bubonic pest, called also the Black Death (6) (7), was characterized by a painful swelling in the lymph nodes known as buboes, and we now know that was caused by a bacillus, a type of bacterium named Yersinia pestis, which was transmitted by the rat fleas (8). Recently, the scientists Susan Scott and Christopher Duncan from Liverpool University have proposed the theory that the Black Death may have been caused by a virus similar to Ebola virus, not by a bacterium (9), although actual epidemiology mostly thinks that the pest is caused by the Yersinia pestis bacterium.

The Tahsil advises how to be protected from the disease and how to prevent infection, and it also indicates guidelines palliative therapy to patients, including recipes of an important dietetic and pharmacological value.

In this treatise, Ibn Khatima was ahead of scientific discoveries of the $19^{\text {th }}$ and $20^{\text {th }}$ centuries, in relation to the theory of contagion and the need for isolation in case of infection, etc, and he comes close to the types of plagues that modern science considers in its classification, I mean, bubonic pest, pneumonic pest and septicemic pest.

Ibn Khatima speaks of "vapors infected by minuscule organisms" that invade the body, causing disease, and that are transmitted from one to another. And so, he emphasizes in the need for isolation in epidemics as a preamble to the modern theories of the epidemiology (10) and the bacteriological microbiology (11) (12).

Section V of the Tahsil is one of the most newfangled and interesting of the book. In this part, Ibn Khatima exposes his theories about the contagion. According to him, the pest is a very serious disease because it is infectious and contagious. The contact with the patient or any of his equipment and vestments is the main cause of infection, due to -as I saidminuscule bodies that are passed from one person to another 
through the air they breathe, although we must also consider the willingness of each one and his own defense, reaction and resistance system. Thus, according to Ibn Khatima, the alteration and corruption of air promote the disease and it spreads through contagion (13), and this is a very close thought to modern epidemiology.

By keeping up the theory from the Bible about the malediction of God as the origin of the plagues, the medieval belief of the divine punishment (14)(15) to the sins committed by humanity as the source of all evils and misfortunes -like is the case of the bubonic pest- is likewise found in the pages of the Tahsil, especially in the doctrinal part of the work, i.e. the chapters VII, VIII, IX and X, where the author, among other things, refers to the behavior that according to orthodox Islam the Muslims should follow in the event of being struck by an epidemic.

\section{Remedies and Recipes for the Treatment of the Bubonic Pest}

Some of the recipes contained in the Tahsil for the treatment of the bubonic pest are the following (folios $77 \mathrm{v}^{\circ}-80 \mathrm{r}^{\circ}$ of the Arabic Manuscript no. 1785 from the Library of El Escorial. Fragments of the Question VI):

In relation to the bubonic pest, you must first examine the patient's statement as well as his strength and the symptoms of the disease. If his body is clean, and he is strong and has mild symptoms; and furthermore if he feels pricks, pain or heaviness in the armpits $\left[\mathbf{f . 7 8}^{\circ}\right]$, together with slight putrefaction in the veins, then you have to rinse the area time and again with rose water mixed with vinegar until the flavor appears. You can also apply on the place a rag soaked with that remedy prepared, replacing it with another when is dry. You will not stop doing that until you are sure that the patient's body is clean, the patient has lot of strength and the disease symptoms are mild, as I have already said. Whatever it may be, the treatment will be used to remove the residue was taken. When are evident a great benefit and the disappearance of the disease without annoyance, and check that in those who were careful to maintain their health, improve their food and clear their bodies, if you show up suddenly and the patient's condition is like we have described and you prescribe remedies absorbing the humors, then you will damage the sick, especially if they are potent absorbents, for indeed you incite the humors in a time when their maturation is easy and possible, thereby causing a new disease that the only thing would stop it, would be that the patient would have evacuated. During this labor, you must worry about the heart and help it to be strong, and you have to be interested in its functioning. And, if you see that the pain returns to the heart increasing, the patient feels that the pain of the armpits is extending up to the heart and he still complains about it, then desist from such treatment being that the abundant residue is aberrant, and its elimination is not possible, as this would take to the patient to death. In addition, if you are not sure that the patient's body is clean and he has lot of strength, and you see that the disease symptoms are mortal, then, first you will use the remedies absorbing of substances $\left[f .78 v^{\circ}\right]$ softly and calming properties until the situation is halfway between the absorption and the elimination in order to the area does not become inflamed for remedies that are strong absorbents and its humor becomes corrupted and swollen, such that the heat and the inflammation arrive at the heart; and consequently, the torture increases and the patient dies.

1-Recipe of one remedy that is good for that: You take 1 ounce of fenugreek and marshmallow, 1/2 ounce of ribgrass and chamomile flowers, and 4 dirhems of basil cultivated. Everything is crushed in a mortar with clear water, barley water or water of green coriander, if there virulence; and if there is not, then with water in which has boiled root of blue iris, until become like a plaster. Later, you take a little of this medicament within a rag and it is placed on the area where the nodules have appeared. When the moisture of the remedy is dried, it will be replaced by a similar one, applying continuously around the area rags soaked in rose water mixed with vinegar in order to it does not swell. This happens frequently and it is bad.

2-If that is enough to stop the swelling, it will be reduced, and if not, it will use this other medicament whose recipe is: You take 4 ounces of rosewater, 1 ounce of acrid vinegar, 1/2 ounce of lemon vinegar or cider vinegar, and 2 dirhems of red sandalwood, white sandalwood and absinthe pills. You crush both sandalwoods and the absinthe and put everything in a rag; afterwards you place the rag in the rosewater mixed with vinegar until the strength of the medicine appears. You will use it like we have mentioned. It is also possible to reinforce the remedy by adding a bit of mucilage of ribgrass and purslane, according to needed and as appropriate.

If $\left[\mathrm{f} .79 \mathrm{r}^{\circ}\right]$ the disease stays beyond the fourth day, which is usually the limit to survive or die, and if the pain persists in the area of the buboes with palpitations that are alarming symptoms of the confluence of the residue already dominated by corruption and pus, if all this happens, then you will know that the substance has separated from the heart and has joined together, and certainly the heart has been released of it, although perhaps it [the heart] is not able to get this until the seventh day, and that according to the humors and the nature of the substances. Using that plaster with water is more potent than the other one to absorb, to extract and to mature.

3-Recipe of one remedy also good for that: You take 1 ounce of linseed, cockscomb and root of blue iris; 12 ounce of kidney fat and goose-flesh; 1 ounce of lily oil; and 4 dirhems of red wax. You dissolve the wax in the oil and you crush the iris root and the seeds thoroughly with water without boiling; although, if you want, you can boil. Later you put it all together in a mortar, you crush it again until thoroughly mixed and you beat it until becoming like the pomade. And then, using a rag, you apply to the affected area a bit of the remedy. You will get the same benefit with an ointment made from blue iris root boiled, crushed and mixed with kidney fat. Too, the fig chewed and mixed with lily oil and a 
little fine salt; either the paste made from barley flour mixed with honey and olive oil; either egg yolk mixed with oil, in which has been boiled blue iris root, or with butter, etc.

If there are signs of maturation and appearance of pus altering the nature of the blood and these signals are increasing after one week, then do not delay in recommending to be lanced the area $\left[\mathbf{f . 7 9} \mathrm{v}^{\mathbf{0}}\right]$ by iron for indeed there is no danger nor ravage in it, while if it is lanced, with the grace of God the Most High you will get to overcome the disease. If it becomes inflamed, you will have to apply soothing and cooling remedies such as egg white beaten with rose oil. And, if it does not become inflamed, then you will apply one linen wick soaked with syrup of oxymel condensed with plantain juice, or without it, according to need, besides healing pomades, and so you will get curing the disease with the grace of God.

If you see that the substance is concentrated but there no maturation (most times that is what happens on thin bodies), then no matter if the area affected is lanced without waiting the appearance of humidity, because once exceeded the maturation and the seventh day, the highlight is the slow oozing, and to leave it without being lanced it would be a great disservice and so you might take with the patient at the beginning of the disease again and the patient would suffer a relapse for a cause banal.

These buboes can also be lanced with medicaments without iron or surgery, if they mature at the beginning according to what we have said. They also could disappear without being lanced depending on the quantity of the substance as well as on the humidity, the thickness and the strength of the body.

You should not puncture them before their maturation and their substance has been detached from the heart in order that the patient does not die suddenly. Be very cautious about it. It happens that, if you puncture these nodules, emerged from the heart and in contact with it and the veins, before their substance comes off the heart, remains concentrated in the body and changes the nature of the blood to the pus, I mean before their maturation, then will bleed [f.80 $\left.\mathbf{r}^{\circ}\right]$, and drag blood through the veins in contact, and consequently the patient will die at once. A scarifier informed me that an ignorant person among those who have broken into this technique ordered him to puncture one nodule under the armpit at the beginning of its appearance before maturation. He punctured it as he ordered, and at that time emanated blood from the nodule, the patient vanished and his heart became corrupted. Finally, without having any kind of improvement, he died.

\section{Weights and Measures}

Dirhem: 1 dirhem is equivalent to $3,12 \mathrm{gr}$.

Ounce: 1 ounce is equivalent to $37 \mathrm{gr}$.
These pages are an example of the relevance of Ibn Khatima in the history of science; and his work entitled Tahsil has a prominent place in the fields of medicine and pharmacology of the Middle Ages.

\section{REFRENCES}

[1] M.Ullmann. Die Medizin im Islam. E.J.Brill, Leiden/Köhl, 246-247, 1970.

[2] M.A.Al-Khattabi. Atteb wa al-atibba fi al-Andalus al-Islamia, Vol.2. Beyrouth, 151-161, 1988.

[3] M.Antuña. Abenjátima de Almería y su tratado de la peste. Religión y cultura, Vol. I, 68-90, 1928.

[4] L.M.Arvide Cambra. Prescripciones médicas de Ibn Jatima para el tratamiento paliativo en la enfermedad de la peste bubónica. European Scientific Journal, Vol. 9, No 18, 13-19, 2013.

[5] L.M.Arvide Cambra. El tratado de la peste de Ibn Jatima (m. 1369). Minotauro Digital, 2012. Online Available from:[http:/www.minotaurodigital.net/textos.asp?art=259\&s eccion=Literatura\&subseccion=articulos.htm]

[6] J.P.Byrne. The Black Death. Greenwood Publishing Group, London, 2004.

[7] Ph.Ziegler. The Black Death. HarperCollins Publishers, London, 1969.

[8] D.T.Dennis, P.S. Mead. Yersinia species, including plague. Principles and Practice of Infectious Diseases. Elsevier Churchill Livingstone, Philadelphia, chapter 229, 2009.

[9] S.Scott, Ch. J. Duncan. Return of the Black Death. The World's Greatest Serial Killer.John Wiley \& Sons, Chichester, West Sussex, 2004.

[10] L.Gordis. Epidemiology. Elsevier Health Sciences, Philadelphia, 2009.

[11] A.Salyeers, D.D.Andwhitt. Bacterial Pathogenesis. American Society from Microbiology, Washington, 1994.

[12] G.J.Tortora,B.R.Funke,Ch.R.Case.Microbiology:An Introduction. Benjamin-Cummings Pub Co, San Francisco, CA, 2009.

[13] J.L.Imbert Palafox. Historia de la infección y el contagio. Elementos. Vol.20, No 3, 37-44, 1994.

[14] A.L.Haindl. La peste negra, 2011. Online Available from:[ht tp://edadmedia.cl/wordpress/wp-content/uploads/2011/04/La PesteNegra.pdf].

[15] J.Arrizabalaga. La Peste Negra de 1348: los orígenes de la construcción como enfermedad de una calamidad social. Dynamis, Vol. 11, 89-90, 1991.

\section{Conclusion}

